\title{
A new, rare and small "lobeattid" species (Insecta: Archaeorthoptera) found at Xiaheyan (Pennsylvanian; Ningxia, China)
}

\author{
Lu Chen ${ }^{1}$, Dong Ren ${ }^{1}$, and Olivier Béthoux ${ }^{2}$ \\ ${ }^{1}$ College of Life Sciences and Academy for Multidisciplinary Studies, Capital Normal University, Beijing, China \\ ${ }^{2}$ CR2P (Centre de Recherche en Paléontologie - Paris), MNHN - CNRS - Sorbonne Université, 57 rue Cuvier, \\ CP38, 75005, Paris, France
}

Correspondence: Dong Ren (rendong@ mail.cnu.edu.cn)

Received: 16 January 2020 - Revised: 9 March 2020 - Accepted: 16 March 2020 - Published: 8 April 2020

\begin{abstract}
A new species of stem Orthoptera, namely $P h$ tanomiamia gui gen. et sp. nov., is described from the Pennsylvanian Xiaheyan locality in China. Despite the intensive collecting efforts undertaken at this locality, a single forewing was recovered. It shares with the "lobeattid" $M i$ amia spp. two peculiar traits, namely a broad ScP-R/RA area and a very early branching of $\mathrm{CuA}+\mathrm{CuPa}$. On the other hand, it displays a free portion of $\mathrm{CuA}$ (between its divergence from $\mathrm{M}+\mathrm{CuA}$ and its fusion with $\mathrm{CuPa}$ ), a trait allowing exclusion of the new species from Miamia, to which it is most likely very closely related.
\end{abstract}

\section{Introduction}

The Xiaheyan locality has yielded an unprecedented number of specimens of early-Pennsylvanian winged insects. Many species could be documented on the basis of large to very large samples, in particular among the stem lineages of Orthoptera (crickets, katydids and grasshoppers), which dominate the various taphocoenoses from which insect remains were recovered (Trümper et al., 2020). For example, species such as Longzhua loculata Gu, Béthoux and Ren, 2011, Miamia maimai Béthoux, Gu, Yue and Ren, 2012b and Protomiamia yangi Du, Béthoux, Gu and Ren, 2017 were described based on several tens of specimens each. However, the undertaken collecting effort also allowed sampling of rare species of stem Orthoptera, including Heterologus duyiwuer Béthoux, Gu and Ren, 2012a and Sinogerarus pectinatus Gu, Béthoux and Ren, 2017, each known from a single, isolated forewing. Herein we report the discovery of another, rare stem-orthopteran species. Because the chances to collect additional material at Xiaheyan are very low, we endeavoured to provide a description despite the meagre sample.

\section{Material and methods}

The studied specimen is housed at the Key Lab of Insect Evolution and Environmental Changes, College of Life Sciences, Capital Normal University, Beijing, China (CNU). It was collected from the locality near Xiaheyan village (Zhongwei City, Ningxia Hui Autonomous Region, China; Yanghugou Formation; latest Bashkirian (latest Duckmantian) to middle Moscovian (Bolsovian), Pennsylvanian; Trümper et al., 2020). The exact layer from which it was collected was not documented.

A draft drawing was produced using a LEICA MZ12.5 dissecting microscope equipped with a drawing tube (Leica, Wetzlar, Germany). The drawing reproduced in Fig. 1a was prepared using Adobe Illustrator CC 17.0.0 (Adobe Systems, San Jose, CA, USA) using both draft and photographs. Photographs were taken using a digital camera Canon EOS 450D (Canon, Tokyo, Japan) coupled to a Canon MP-E $65 \mathrm{~mm}$ macro lens (equipped with polarizing filter). The resulting photographs were optimized using Adobe Photoshop CC 2015.5. The photograph reproduced in Fig. $1 \mathrm{~b}$ is a combination of photographs of the dry specimen and when immersed in ethanol. 
(a)
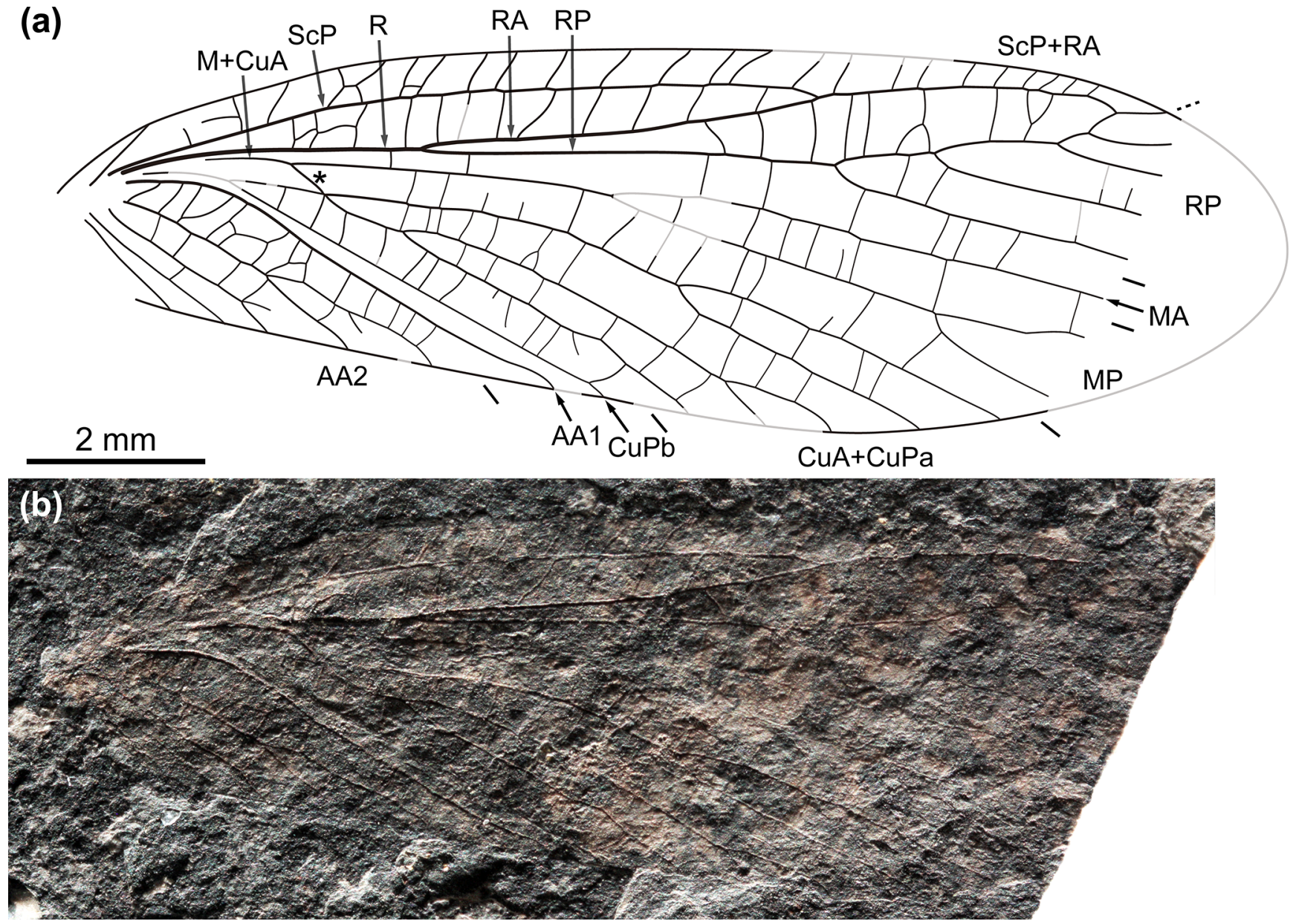

Figure 1. Phtanomiamia gui gen. et sp. nov., holotype (specimen CNU-NX1-324): (a) interpretative drawing (the asterisk indicates the free portion of $\mathrm{CuA}$ ) and (b) photograph (composite, light mirrored).

We use the wing venation homologies elaborated by Béthoux and Nel (2002) for Archaeorthoptera. Corresponding abbreviations are the following: ScP, posterior subcosta; $\mathrm{R}$, radius; RA, anterior radius; $\mathrm{RP}$, posterior radius; $\mathrm{M}$, media; $\mathrm{CuA}$, anterior cubitus; $\mathrm{CuP}$, posterior cubitus; $\mathrm{CuPa}$, anterior branch of $\mathrm{CuP} ; \mathrm{CuPb}$, posterior branch of $\mathrm{CuP} ; \mathrm{AA}$, anterior analis; AA1, first anterior analis; AA2, second anterior analis.

\section{Systematic description}

Taxon Archaeorthoptera Béthoux and Nel, 2002

Family incertae sedis

Phtanomiamia Chen, Ren and Béthoux gen. nov.

(urn:1sid:zoobank.org: 3FAEB099-6FAA-473F-899D89BA96B9C729)

\section{Type species}

Phtanomiamia gui sp. nov.

\section{Gender}

Masculine.

\section{Etymology}

A combination of "phtanos", "come earlier" in ancient Greek, and "Miamia", the name of a related genus; referring to close proximity of the new genus with Miamia spp.

\section{Diagnosis}

By monotypy, as for the type species. 
Phtanomiamia gui Chen, Ren and Béthoux sp. nov.

(urn:1sid:zoobank.org: 1AC9FA32-A6B7-4AD89CDA-DADE964B9271

(Fig. 1)

\section{Type species}

Phtanomiamia gui sp. nov.

\section{Material}

Holotype only, CNU-NX1-324, deposited at the CNU.

\section{Etymology}

The species name is dedicated to Junjie $\mathrm{Gu}$, for his contributions to fieldwork at Xiaheyan and to the systematics of Orthoptera.

\section{Diagnosis}

Forewing: ScP-R/RA area broad (at its broadest, broader than the area between the anterior wing margin and $\mathrm{ScP}$ ); first fork of $\mathrm{M}$ in a distal position (distal to the second fifth of wing length, basal to wing mid-length); $\mathrm{CuA}+\mathrm{CuPa}$ branched shortly after the fusion of $\mathrm{CuA}$ and $\mathrm{CuPa} ; \mathrm{CuA}$ with a distinct, free portion between its divergence from $\mathrm{M}+\mathrm{CuA}$ and its fusion with $\mathrm{CuPa}$.

\section{Description}

Holotype specimen (CNU-NX1-324): negative imprint of an isolated, left forewing, apex missing; preserved length about $12.2 \mathrm{~mm}$, estimated length about $13.8 \mathrm{~mm}$, maximum width $4.2 \mathrm{~mm}$; ScA present, short; ScP-R/RA area broader than area between anterior wing margin and $\mathrm{ScP}$; area between the anterior wing margin and $\mathrm{ScP} / \mathrm{ScP}+\mathrm{RA}$ with strong crossveins, mostly oblique and simple, reticulated near the wing base; ScP reaching RA slightly basal to the second third of wing length; RA/RP fork slightly basal to the first third of wing length; RA simple; RA and RP close and parallel until wing mid-length, where both veins diverge; RP simple for $4.7 \mathrm{~mm}$, posteriorly pectinate (as preserved), with five branches preserved, the anterior-most one reaching RA; M weak, simple for $3.7 \mathrm{~mm}$ before it forks into MA and MP; MA simple (as preserved), MP with two preserved branches (it probably possessed 3); $\mathrm{CuA} 0.5 \mathrm{~mm}$ long before its fusion with $\mathrm{CuPa} ; \mathrm{CuA}+\mathrm{CuPa}$ forked immediately after the fusion of $\mathrm{CuA}$ and $\mathrm{CuPa} ; \mathrm{CuA}+\mathrm{CuPa}$ with a total of five branches $(2,3)$; $\mathrm{CuPb}$ simple and straight; area between $\mathrm{CuPb}$ and AA1 narrow; AA1 strong and simple, some cross-vein between AA1 and AA2 have cross-veins between them; AA2 with six branches; cross-veins occasionally reticulated; no colouration pattern visible.

\section{Locality and horizon}

Xiaheyan Village, Zhongwei City, Yanghugou Formation (Ningxia Hui Autonomous Region, China); latest Bashkirian (latest Duckmantian) to middle Moscovian (Bolsovian), early Pennsylvanian (Trümper et al., 2020).

\section{Discussion}

The new specimen can be confidently assigned to Archaeorthoptera as it exhibits the character "CuA (diverging from $\mathrm{M}+\mathrm{CuA}$ ) fused with the anterior branch of $\mathrm{CuP}(\mathrm{CuPa})$ ", which is the defining character state of this taxon (Béthoux, 2007). Conversely, assignment to the Panorthoptera (including crown Orthoptera and stem groups closely related to them) can be excluded, as $\mathrm{CuPa}$ is not branched before its fusion with $\mathrm{CuA}$. Non-panorthopteran Archaeorthoptera include "lobeattid" insects, the order Cnemidolestodea Handlirsch, 1937 (which is probably derived from a subset of lobeattid insects) and a number of unplaced species. The new specimen displays an RA-RP area narrow for a long distance, a trait occurring in the former, represented at $\mathrm{Xi}$ aheyan by Sinopteron huangheense Prokop and Ren, 2007, Chenxiella liuae Liu, Ren and Prokop, 2009, L. loculata, M. maimai and Pr. yangi. Among lobeattids, the new specimen shares with Miamia spp. (here considered to include Aviologus duquesnei Coty, Háva, Prokop, Roques and Nel, 2014; and see Béthoux, 2008; Béthoux et al., 2012b; Béthoux and Jarzembowski, 2010) a comparatively broad ScP-R/RA area. Another peculiar trait shared with the corresponding species (but not unique to Miamia spp.) is the very early branching of $\mathrm{CuA}+\mathrm{CuPa}$. However, the new specimen lacks the defining character state of Miamia, namely "in forewings, $\mathrm{CuPa}$ fuses with $\mathrm{M}+\mathrm{CuA}$ " (Béthoux, 2008), a condition implying that $\mathrm{CuA}$ does not possess a free portion between its divergence from $\mathrm{M}+\mathrm{CuA}$ and its fusion with $\mathrm{CuPa}$. This free portion of $\mathrm{CuA}$ is present in the new specimen, which represents a plesiomorphy within Archaeorthoptera. In summary, the new specimen belongs to a species closely related to Miamia, yet it can be confidently excluded from this genus. It follows that it belongs to a new species to be accommodated in its own genus. Phtanomiamia gui is smaller than any known species of Miamia, and among the smallest "lobeattid" species.

Data availability. The new material included in the paper is accessible and deposited in the Capital Normal University, Beijing, China, and all data are included in the description.

Author contributions. LC and OB contributed the descriptive section (including preparation of the illustration). LC, DR and OB contributed the Discussion. 
Competing interests. The authors declare that they have no conflict of interest.

Acknowledgements. We are grateful to two anonymous reviewers for their constructive comments. We thank the numerous students who, over the years, contributed to fieldwork at Xiaheyan.

Financial support. Dong Ren was supported by grants from the National Natural Science Foundation of China (grant nos. 31730087 and 41688103), the Program for Changjiang Scholars and Innovative Research Team in University (grant no. IRT-17R75), and Project of High-level Teachers in Beijing Municipal Universities (grant no. IDHT20180518).

Review statement. This paper was edited by Florian Witzmann and reviewed by two anonymous referees.

\section{References}

Béthoux, O.: Cladotypic taxonomy applied: titanopterans are orthopterans, Arth. Syst. Phyl., 65, 135-156, 2007.

Béthoux, O.: Revision and phylogenetic affinities of the lobeattid species bronsoni Dana, 1864 and silvatica Laurentiaux \& Laurentiaux-Vieira, 1980 (Pennsylvanian; Archaeorthoptera), Arth. Syst. Phyl., 66, 145-163, 2008.

Béthoux, O. and Jarzembowski, E. A.: New basal neopterans from Writhlington (UK, Pennsylvanian), Alavesia, 3, 87-96, 2010.

Béthoux, O. and Nel, A.: Venation pattern and revision of Orthoptera sensu nov. and sister groups. Phylogeny of Palaeozoic and Mesozoic Orthoptera sensu nov., Zootaxa, 96, 1-88, https://doi.org/10.11646/zootaxa.96.1.1, 2002.

Béthoux, O., Gu, J.-J., and Ren, D.: A new Upper Carboniferous stem-orthopteran (Insecta) from Ningxia (China), Insect Sci., 19, 153-158, https://doi.org/10.1111/j.1744-7917.2011.01468.x, 2012a.
Béthoux, O., Gu, J., Yue, Y., and Ren, D.: Miamia maimai n. sp., a new Pennsylvanian stem-orthopteran insect, and a case study on the application of cladotypic nomenclature, Foss. Rec., 15, 103-113, https://doi.org/10.1002/mmng.201200008, 2012b.

Coty, D., Háva, J., Prokop, J., Roques, P., and Nel, A.: New archaeorthopteran insects from the Late Carboniferous of the Nord and Pas-de-Calais basins in northern France (Insecta: Cnemidolestodea, Panorthoptera), Zootaxa, 3878, 462-470, https://doi.org/10.11646/zootaxa.3878.5.4, 2014.

Du, S., Béthoux, O., Gu, J., and Ren, D.: Protomiamia yangi gen. et sp. nov. (Early Pennsylvanian; Xiaheyan, China), a sexually dimorphic Palaeozoic stem-Orthoptera, J. Syst. Palaeontol., 15, 193-204, https://doi.org/10.1080/14772019.2016.1154899, 2017.

Gu, J., Béthoux, O., and Ren, D.: Longzhua loculata n. gen. and n. sp., one of the most completely documented Pennsylvanian Archaeorthoptera (Insecta; Ningxia, China), J. Paleontol., 85, 303314, https://doi.org/10.1666/10-085.1, 2011.

Gu, J.-J., Béthoux, O., and Ren, D.: A new, rare and distinctive species of Panorthoptera (Insecta, Archaeorthoptera) from the Upper Carboniferous of Xiaheyan (Ningxia, China), Foss. Rec., 20, 253-57, https://doi.org/10.5194/fr-20-253-2017, 2017.

Handlirsch, A.: Neue Untersuchungen über die fossilen Insekten mit Ergänzungen und Nachträgen sowie Ausblicken auf phylogenetische, palaeogeographische und allgemein biologische Probleme. I Teil, Ann. Naturhist. Mus. Wien, 48, 1-140, 1937.

Liu, Y., Ren, D., and Prokop, J.: Discovery of a new Namurian archaeorthopterid from Ningxia, China (Insecta: Archaeorthoptera), Zootaxa, 2032, 63-68, 2009.

Prokop, J. and Ren, D.: New significant fossil insects from the Upper Carboniferous of Ningxia in northern China (Insecta: Palaeodictyoptera, Archaeorthoptera), Eur. J. Entomol., 104, 267-275, 2007.

Trümper, S., Schneider, J. W., Nemyrovska, T., Korn, D., Linnemann, U. G., Ren, D., and Béthoux, O.: Age and depositional environment of the Xiaheyan insect fauna, embedded in marine black shales (Early Pennsylvanian, China), Palaeogeogr. Palaeocl., 538, 109444, https://doi.org/10.1016/j.palaeo.2019.109444, 2020. 